\title{
A Comparative Research on Internet Usage Time and Digital Literacy of University Students in accordance with Their Major
}

\author{
Beak Song Yi \\ Department of Educational Technology, Korea University, Korea
}

\begin{abstract}
The purpose of this research is to investigate and analyze the computer literacy ability level of Korean college level students. It also analyzed if there are disparities in the computer literacy ability level between the students who are majoring in computer related majors who are expected to have higher computer information ability and the students who are majoring in humanities courses who are expected to have higher critical thinking ability. The analysis was done focusing on the relevancy of computer literacy and hours of using computer. I formed research problems and by using 'computer literacy ability evaluation questions', used descriptive statistics and ran correlation analysis to analyze the general characteristics of 60 students from $K$ University of Korea. As a result, the students who are majoring in humanities courses are found to have higher hours of using computer than the students who are majoring in computer related majors. Humanities courses students had more difficulties in computer technology application items but there was no significant difference in internet information application and community information sharing ability. Also, the computer technology application had no significant effect on the computer literacy. On the other hand, what showed significant correlation with hours of using internet among computer literacy abilities was community information sharing ability? Therefore, educational approach of which recreation of knowledge is possible is needed. If educational program that can develop critical and cooperative thinking and computer technology application education of humanity courses combine, recreation of knowledge will be possible.
\end{abstract}

Abstract

\section{Introduction}

Information society which emerged from information and communication technology such as computer and internet is gradually evolving into a knowledge-based society. The core competency required for people living in a knowledge-based society is the ability to think critically and solve problems by the means of communication facilitated by knowledge and skills necessary in life acquired through digital information and technology - to which we pertain as digital literacy [7]. Korea is at lead in the field of smart device and technology.
However, digital literacy of its people has to be at the same pace with the growing speed of technology in order for the country to maintain its lead as the top IT country. Initial discussions on digital literacy were mostly in terms of utilization of computer or the application of internet. But the focus has evolved from a simple usage of ICT into a concept: ways of searching, analyzing, and evaluating, organizing, creating, applying and managing, communicating and ethical thinking on all sorts of information needed by information technology.

In fact, analytical studies and information education on digital literacy mainly focuses on elementary, middle and high school students. Tapscott defined Americans aged 11 to 33 as "digital native" (based on year 2008); which stands for people who grew in a digital generation. The distinctive characteristics of a digital generation are that they give emphasis on discussion, proving, criticizing and information sharing skills. The current university students hold the highest education level in this digital generation and can be said to be the most active, as well as leading group in the knowledge ground of the 21 st century. Digital literacy is an essential competent skill to become a professional labor to survive the knowledge and information-based society. Therefore, students with low digital literacy will have low level on social adaptability [2].

Meanwhile upon the introduction of a new technology, Lee Jaehyun presented a new concept of "time re-allocation"; which asserts that time is distributed all throughout $\mathfrak{k}$ daily life. The time spent on internet does not only affect the time used on television, newspaper, radio like traditional media but also on time spent for necessary activities such as sleeping, eating and also leisure activities and labor activities. All sorts of digital activities are made through desktop, laptop, smart phones, smart TV, and cloud based devices all along the daily lives of Korean university students. Therefore, this study aims to research and analyze the digital literacy of Korean university students. In addition, difference in digital literacy in accordance with their majors shall be analyzed by comparing students with a computer-related course whom we think have a high information competency with students with a humanities course who may have high critical cognitive capability. The relationship between digital literacy level based on time re-allocation concept and 
the time spent online will be studied in order to complement the indicator frame of digital literacy.

- $\quad$ Research subject 1: Is there a difference in the internet usage time of the university students according to their major?

- Research subject 2: Is there a difference in digital literacy of the university students according to their major?

- Research subject 3: Is there any relationship between internet usage time and digital literacy?

\section{Theoretical Background}

\subsection{Digital Literacy}

Digital literacy is not just the ability to use the computer but to evaluate the values of information found over the internet and think critically. It also pertains to the ability to understand various forms of information from various sources and recreate the information according to the purpose of usage. Larson similarly defined digital literacy as the ability to understand and apply various kinds of information from different sources over the internet. Gilster in his book 'Digital Literacy,' criticizes that digital literacy is being misinterpreted as a simple skill whose purpose merely lies on the technology itself. Moreover, he asserts that everything revolves around critical thinking, and internet and digital literacy is necessary for survival Jeongsun Han define digital literacy as the ability to appreciate the necessity of information in a fast changing digital environment and the ability to collect, organize, evaluate and integrate the needed information through various digital media. In another words, in order for one to be called to have digital literacy, he/she should be able to recognize the importance of information collect information through various media and technology afterward. Further, he/she should be able to identify the collected information [3]. If the information is filtered out well, this should help not only in solving problems but also in creating a new knowledge by combining various information through the digital sources. A digitally literate person should develop into a mature citizen who complies with the right regulations and communicates using high quality knowledge and information in a digital society like today.

\subsection{Components of Digital Literacy}

Literacy is classified into photo-visual, reproduction, branching, and information and socio-emotional. It can be noted that socio-emotional is included in the literacy range but as the ranges are limited and are focused more on visual media, photo and image than on technology literacy, it is difficult to reflect on the framework development. Level of literacy differs in every generation. With the arrival of a new generation, the required levels of literacy have hiked, calling for additional skills and knowledge. This means that literacy is not a category but possesses a continuous property. Upon the emergence of the information era, 3Rs have been substituted with $4 \mathrm{E}$ therefore a new literacy is rising to be in demand [3][5].

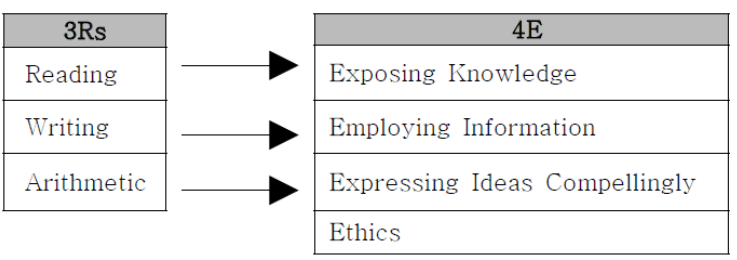

Figure 1. 3Rs and 4E

\subsection{Definition of Terms in Digital Literacy Indicator}

\subsubsection{Computer usage ability}

This is defined as the process of learning function operations, basic skills, and internet usage abilities. Utilization of computer skills is categorized into four: basic computer usage skills, Windows operation skills, program utilization skills and internet maneuvering skills [5].

\subsubsection{Internet information usage ability}

This is defined as ability to utilize information such as creating, processing, analyzing, searching and using information. Internet information usage ability is composed of 6 areas including information necessity recognition ability, information searching ability, information analysis and generation ability, information organization and usage ability, information search process and results evaluation ability and information ethics evaluation ability [1], [5].

\subsubsection{Community information sharing ability}

This is defined as the ability to create new information, that is to say, new knowledge, based on the acquired information. Community information sharing ability is composed of 3 areas which are ability to utilize community technology, ability to 
recognize and utilize information sharing and ability to evaluate community ethics [1][5].

\subsection{Research trends of digital literacy indicator}

According to Kim Min $\mathrm{Ha}$ and $\mathrm{Ahn} \mathrm{Mi} \mathrm{Ri}$, an improved, and more comprehensive sense of digial literacy includes computer literacy, information literacy and knowledge literacy. Computer literacy pertains to the ability to acquire basic skills and information access skills such as operation and utilization of information technology [1]. Information literacy pertains to the ability to utilize information such as creating, processing, analyzing, searching and utilizing of information. Knowledge literacy, they say, is the ability to create information to generate and deliver new information knowledge- based on the acquired information. Among these 3 areas of literacy, the first area is composed of a total of 46 items including basic computer handling ability, windows operation ability, program usage ability, and internet operation ability. The indicator that shows computer literacy capability is as follows. Minha Kim and Miri Ahn developed 116 question items in order to evaluate digital literacy level [1][5].

Table 2 . Digital literacy indicator

\begin{tabular}{|c|c|}
\hline Knowledge literacy skills & Index \\
\hline \multirow[t]{2}{*}{ Ability to use community techniques } & Understanding on community \\
\hline & Ability to technically utilize the community \\
\hline \multirow[t]{5}{*}{$\begin{array}{l}\text { Ability to recognize and apply community } \\
\text { information sharing }\end{array}$} & $\begin{array}{l}\text { Appreciation of sharing ideas and information with others through the } \\
\text { community }\end{array}$ \\
\hline & Ability to select an appropriate community \\
\hline & Ability to extract and show information through the community \\
\hline & $\begin{array}{l}\text { Ability to create new information and knowledge using the community's } \\
\text { information }\end{array}$ \\
\hline & $\begin{array}{l}\text { Information and knowledge creation through the exchange of information } \\
\text { and ideas with the experts and others }\end{array}$ \\
\hline \multirow[t]{2}{*}{ Community ethics evaluation ability } & Sense of community \\
\hline & Protection of ideas and information from the community \\
\hline
\end{tabular}

\subsubsection{Level of digital literacy}

According to Han Jeongsun's study, digital literacy is made up of levels: the amateur ability level of "remembering / understanding", the intermediate level of "applying/ analyzing/ evaluating", and lastly the professional level of "creating". Such level structure is-not specifically mentioned in the current educational curriculum. Instead, the levels are already integrated in the contents. However, the "general activity" in the curriculum of the computer field is equivalent to the highest professional "creating" level [5]. Digital literacy frame based on the levels is as follows. Reconstruction and copyright of information, privacy protection and social responsibility have been added.

\section{Methodology}

\subsection{Subjects of the Study}

The study's subjects are 3rd and 4th year university students with the highest educational level among the major digital natives raised in a digital environment (based on the year 2008, aged 11 to 31) The survey was distributed randomly in offline universities in Seoul. Thirty students from a computer-related course (Computer science and engineering, information technology/communication, computer education) and thirty students from a humanities-related course (education philosophy, philosophy, literature) were chosen as the subjects of the study. The survey was conducted online, with the URL of the questionnaire sent out through the respondents' email and SNS. 


\subsection{Hypotheses of the study}

The study models and hypotheses with the respondents as its subjects are as follow:

- Hypothesis 1: Students from a computerrelated course spend more time using internet than those students from a course not related to computer.

- Hypothesis 2: Students from a computerrelated course-have higher digital literacy than students from a course not related to computer Hypothesis 2-1: Students from a computerrelated course have higher digital computer literacy than students from a course not related to computer Hypothesis 2-2: Students from a computer-related course have higher digital information literacy than students from a course not related to computer

- Hypothesis 2-3: Students from a computerrelated course have higher digital knowledge literacy than students from a course not related to computer-

- Hypothesis 3: More internet usage time leads to higher digital literacy.

\subsection{Analysis method}

\subsubsection{Digital Literacy Checklist Questionnaire}

The analysis of this study was implemented by using SPSS 12.0. Before the verification of the hypotheses, the respondents' characteristics were identified by analyzing the demographical variables. In order to verify the hypotheses on the research subject 1 and 2 , $\mathrm{T}$ verification on independent samples were executed and correlation analysis was executed to verify the hypothesis on research subject 3.

\subsection{Study Tools (digital literacy check list)}

As its study tool, a digital literacy skill checklist modified by Kim Minjeong [7] that was made by Hanjeongsun et al. [5] was used. All constituting factors were credited with their Cronbach's alpha value resulting to a 0.796 . The number and contents of the study's digital literary checklist items are as follows:

Table 3. digital literacy skill checklist modified by Kim Minjeong (2010)

\begin{tabular}{|c|c|c|c|}
\hline Coverage & & $\begin{array}{l}\text { Question } \\
\text { Number }\end{array}$ & $\begin{array}{l}\text { Number of } \\
\text { Questions }\end{array}$ \\
\hline \multirow{5}{*}{$\begin{array}{l}\text { Computer skills utilization } \\
\text { ability }\end{array}$} & Basic computer operation ability & $1-6$ & 6 \\
\hline & Windows operating ability & $7-12$ & 6 \\
\hline & Program utilization ability & 13,14 & 2 \\
\hline & Internet operating ability & 15,16 & 2 \\
\hline & Total number of questions & & 16 \\
\hline \multirow[t]{6}{*}{ Internet data utilization ability } & Ability to recognize the need for data & $1-3$ & 3 \\
\hline & Data searching ability & $4-13$ & 10 \\
\hline & Data analyzing and extraction ability & 14-19 & 6 \\
\hline & Data structure and utilization ability & $20-23$ & 4 \\
\hline & Data search processing and output evaluation ability & $24-28$ & 5 \\
\hline & Data ethnics evaluation ability & $29-33$ & 5 \\
\hline \multirow{4}{*}{$\begin{array}{l}\text { Community data sharing } \\
\text { ability }\end{array}$} & Community skills utilization ability & $1-4$ & 3 \\
\hline & Ability to recognize and utilize community data & $5-11$ & 4 \\
\hline & Community ethnics evaluation ability & $12-18$ & 7 \\
\hline & Total number of questions & & 7 \\
\hline \multirow[t]{6}{*}{ General information } & Gender & 1 & 1 \\
\hline & Year & 2 & 1 \\
\hline & Major & 3 & 1 \\
\hline & Experience of taking E-learning lecture & 4 & 1 \\
\hline & Total number of questions & & 4 \\
\hline & Total number of all questions & & 71 \\
\hline
\end{tabular}




\section{Result and Interpretation}

In order to analyze the general characteristics of the respondents, analysis of frequency was executed on all respondents' sex, age, course, year level, internet usage duration, number of devices used, the major device being used when using the internet, and average time a day spent on internet male (15 persons, $25.0 \%$ ) participated less than female (44, $73.3 \%$ ) in terms of the number of respondents. In terms of age 17 persons $(28.3 \%)$ were aged 23,7 persons $(11.7 \%)$ were aged 24,6 persons $(10.0 \%$, were aged 25, 11 persons (18.3\%) were aged 26, 3 persons $(5.0 \%)$ were aged 27,9 persons $(15.0 \%)$ were aged 28, and 6 persons( $10 \%$ ) were aged 29; thus people aged 23 having participated the most. The courses of the respondents are the following: respondents from a computer-related course were 29 persons $(28.3 \%)$ and respondents from a course unrelated to computer were 30 persons $(50 \%)$. For the year level, 19 persons $(31.7 \%)$ were junior, and 40 persons $(66.7 \%)$ were senior. As for the years of internet usage among the respondents, the statistics were found to be as follow: less than 1 year had 1 respondent, (1.7\%), 1 5 years had $4(6.7 \%), 6 \sim 10$ years had 14-(23.3\%), 11 15 years had $32(53.3 \%)$, and 16 20 years had 8 (13.3\%); most people having been using the internet for 11 15 years. For the number of device used for internet; 1 device had 8 respondents (13.3\%), 2 devices had 40 (66.7\%), 3 4 devices had 9, more than 7 devices had 2 (3.3), most people used around 2 devices for using the internet. For the types of device for using the internet, smart tv was used by one person $(1.7 \%)$, smart phones (cellular phones) by 25 persons (41.7\%), desktop/laptop by 31 persons $(51.7 \%)$ and tablet pc by 2 persons (3.3\%); most people used desktop and laptop. Average time spent on internet per day was the following: below 1 hour by 5 persons $(8.3 \%)$, $1 \sim 3$ hours by 28 persons (46.7\%), 4 6 hours by 16 persons (26.7\%), 7 9 hours by 3 persons $(5.0 \%)$ and more than 10 hours by 6 persons $(10 \%)$; most people spent 1 3 hours in average on the internet per day. All these statistics are arranged in the Table 4.

Table 4. The general characteristics of respondents

\begin{tabular}{|c|c|c|c|}
\hline$\overline{\text { Division }}$ & & Frequency(person) & Ratio(\%) \\
\hline \multirow[t]{4}{*}{ Gender } & Male & 15 & 25.0 \\
\hline & Female & 44 & 73.3 \\
\hline & Missing & 1 & 1.7 \\
\hline & Total & 60 & 100 \\
\hline \multirow[t]{9}{*}{ Age } & 23 & 17 & 28.3 \\
\hline & 24 & 7 & 11.7 \\
\hline & 25 & 6 & 10.0 \\
\hline & 26 & 11 & 18.3 \\
\hline & 27 & 3 & 5.0 \\
\hline & 28 & 9 & 15.0 \\
\hline & 29 & 6 & 10.0 \\
\hline & Missing & 1 & 1.7 \\
\hline & Total & 60 & 100 \\
\hline \multirow[t]{4}{*}{ Major } & Computer-related majors & 29 & 48.3 \\
\hline & Computer-non related majors & 30 & 50.0 \\
\hline & Missing & 1 & 1.7 \\
\hline & Total & 60 & 100 \\
\hline \multirow[t]{4}{*}{ Grade } & Grade 3 & 19 & 31.7 \\
\hline & Grade 4 & 40 & 66.7 \\
\hline & Missing & 1 & 1.7 \\
\hline & Total & 60 & 100 \\
\hline \multirow[t]{3}{*}{ Internet use time } & Less than $1 \mathrm{yr}$ & 1 & 1.7 \\
\hline & $1-5$ yrs & 4 & 6.7 \\
\hline & $6-10 \mathrm{yrs}$ & 14 & 23.3 \\
\hline
\end{tabular}




\begin{tabular}{|c|c|c|c|}
\hline & $11-15 \mathrm{yrs}$ & 32 & 53.3 \\
\hline & $16-20 \mathrm{yrs}$ & 8 & 13.3 \\
\hline & Missing & 1 & 1.7 \\
\hline & Total & 60 & 100 \\
\hline \multirow{6}{*}{$\begin{array}{l}\text { Number of the } \\
\text { equipment used }\end{array}$} & 1 & 8 & 13.3 \\
\hline & 2 & 40 & 66.7 \\
\hline & $3-4$ & 9 & 15.0 \\
\hline & More than 7 & 2 & 3.3 \\
\hline & Missing & 1 & 1.7 \\
\hline & Total & 60 & 100 \\
\hline \multirow{6}{*}{$\begin{array}{l}\text { Equipment type used } \\
\text { commonly }\end{array}$} & Smart TV & 1 & 1.7 \\
\hline & Smartphone/Mobile phone & 25 & 41.7 \\
\hline & Desktop/Laptop & 31 & 51.7 \\
\hline & Tablet PC & 2 & 3.3 \\
\hline & Missing & 1 & 1.7 \\
\hline & Total & 60 & 100 \\
\hline \multirow{7}{*}{$\begin{array}{l}\text { Internet use time on } \\
\text { daily average }\end{array}$} & Less than $1 \mathrm{hr}$ & 5 & 8.3 \\
\hline & $1-3 \mathrm{hrs}$ & 28 & 46.7 \\
\hline & $4-6 \mathrm{hrs}$ & 16 & 26.7 \\
\hline & $7-9$ hrs & 3 & 5.0 \\
\hline & More than $10 \mathrm{hrs}$ & 6 & 10.0 \\
\hline & Missing & 1 & 1.7 \\
\hline & Total & 60 & 100 \\
\hline
\end{tabular}

\subsection{Difference in computer skill application ability according to the major}

Individual sampling (t) inspection was implemented to study the difference in skill application skills according to the major. One of the results from the computer-related course group was excluded in the analysis. As a result of analysis, there was a noticeable difference in the students' computer skills application ability as per major. As postulated in hypothesis 2-1, students from a computer-related course had higher computer skills application ability, thus validating hypothesis 2-1 The results are summarized in Table 4 .

Table 4. Independent sample t-test for the difference as per major in the ability to use computer technology

\begin{tabular}{cccccc}
\hline Major & $\mathrm{N}$ & Mean & $\begin{array}{c}\text { Standard } \\
\text { deviation }\end{array}$ & $\begin{array}{c}\text { Standard error } \\
\text { of the mean }\end{array}$ & $\begin{array}{c}\mathrm{t} \\
\text { probability }\end{array}$ \\
\hline $\begin{array}{c}\text { Computer-related } \\
\text { majors }\end{array}$ & 29 & 4.196 & .5982 & .111 & $.002 * *$ \\
\hline $\begin{array}{c}\text { Computer-non related } \\
\text { majors }\end{array}$ & 30 & 3.688 & .6185 & .113 & \\
\hline$* * \mathrm{p}<.005$ & & & &
\end{tabular}

\subsection{Difference in internet information} application skill according to the major

Individual sampling (t) inspection was implemented to study the difference in internet information application skill according to the major. Missing occurrence on computer related course group was excluded in the analysis. As a result of analysis, there was no noticeable difference with the internet information application skill by the major of the students. Unlike the hypothesis 2-2 which predicted that the computer related course majoring students would have higher internet information application skills; there was no difference between the two groups. In the other words, the hypothesis 2-2 was dismissed. The results are summarized in Table 5. 
Table 5. Independent sample t-test for the difference in an ability of using Internet information according to majors

\begin{tabular}{cccccc}
\hline Major & $\mathrm{N}$ & Mean & $\begin{array}{c}\text { Standard } \\
\text { deviation }\end{array}$ & $\begin{array}{c}\text { Standard error } \\
\text { of the mean }\end{array}$ & $\begin{array}{c}\mathrm{t} \\
\text { probability }\end{array}$ \\
\hline $\begin{array}{c}\text { Computer-related majors } \\
\text { Computer-non related majors }\end{array}$ & 28 & 3.660 & .502 & .095 & -.010 \\
\cline { 2 - 6 }
\end{tabular}
$* * \mathrm{p}<.005$

\subsection{Difference in community information} sharing skills according to the major

Individual sampling $\mathrm{t}$ inspection was executed to check whether there is a difference in community information sharing skills according to the majors of the university students. Missing occurrences of computer related and unrelated course majoring students were excluded in the analysis. As a result of the analysis there was no seemingly noted difference. Unlike the hypothesis 2-3 which stated that the computer related students may have higher communication information sharing skills, there was no difference between the two groups. So the hypothesis 2-3 was dismissed. The results are summarized in the Table 6.

Table 6. Independent sample t-test for the difference in an ability of sharing community information according to majors

\begin{tabular}{ccccccc}
\hline Major & $\mathrm{N}$ & Mean & $\begin{array}{c}\text { Standard } \\
\text { deviation }\end{array}$ & $\begin{array}{c}\text { Standard error } \\
\text { of the mean }\end{array}$ & $\begin{array}{c}\text { t } \\
\text { Significance } \\
\text { probability }\end{array}$ \\
\hline $\begin{array}{c}\text { Computer-related } \\
\text { majors }\end{array}$ & 28 & 4.108 & .498 & .094 & -.025 & .980 \\
\hline $\begin{array}{c}\text { Computer-non related } \\
\text { majors }\end{array}$ & 28 & 4.112 & .661 & .125 & & \\
\hline
\end{tabular}

\subsection{Relationship between internet usage time and-digital literacy}

A correlation analysis was executed to study the relationship between internet usage time and digital literacy. As the result of the analysis, only the community information sharing skills among all digital literacy skills was found out to have a significant relationship with internet usage time. In addition, the three skills stated below also had some significant relationship with digital literacy skills. Check the Table 7 for the summarized results.

Table 7. The relationship between internet use time and digital literacy skills

\begin{tabular}{|c|c|c|c|c|c|c|}
\hline & & $\begin{array}{l}\text { Ability of using } \\
\text { computer } \\
\text { technology }\end{array}$ & $\begin{array}{l}\text { Ability of using } \\
\text { internet } \\
\text { information }\end{array}$ & $\begin{array}{l}\text { Ability of } \\
\text { sharing } \\
\text { community } \\
\text { information }\end{array}$ & $\begin{array}{l}\text { Internet } \\
\text { time }\end{array}$ & use \\
\hline \multirow[t]{3}{*}{$\begin{array}{l}\text { Ability of using } \\
\text { computer technology }\end{array}$} & $\begin{array}{l}\text { Pearson's correlation } \\
\text { coefficient }\end{array}$ & 1 & .487 & .535 & .067 & \\
\hline & $\begin{array}{l}\text { Significance } \\
\text { probability (both) }\end{array}$ & & $.000 * * *$ & $.000 * * *$ & .620 & \\
\hline & $\mathrm{N}$ & 59 & 58 & 56 & 58 & \\
\hline \multirow[t]{3}{*}{$\begin{array}{l}\text { Ability of using } \\
\text { internet information }\end{array}$} & $\begin{array}{l}\text { Pearson's correlation } \\
\text { coefficient }\end{array}$ & .487 & 1 & .707 & .170 & \\
\hline & $\begin{array}{l}\text { Significance } \\
\text { probability (both) }\end{array}$ & $.000 * * *$ & & $.000 * * *$ & .206 & \\
\hline & $\mathrm{N}$ & 58 & 58 & 56 & 57 & \\
\hline \multirow{3}{*}{$\begin{array}{l}\text { Ability of } \\
\text { community } \\
\text { information }\end{array}$} & $\begin{array}{l}\text { Pearson's correlation } \\
\text { coefficient }\end{array}$ & .53 & .707 & 1 & .282 & \\
\hline & $\begin{array}{l}\text { Significance } \\
\text { probability (both) }\end{array}$ & $.000 * * *$ & $.000 * * *$ & & $.037 *$ & \\
\hline & $\mathrm{N}$ & 56 & 56 & 56 & 55 & \\
\hline Internet use time & Pearson's correlations & .067 & .170 & .282 & 1 & \\
\hline
\end{tabular}




\begin{tabular}{llllll}
\hline & $\begin{array}{l}\text { Significance } \\
\text { probability (both) }\end{array}$ & .620 & .206 & $.037^{*}$ & \\
\cline { 2 - 5 } & $\mathrm{N}$ & 58 & 57 & 55 & 58 \\
\hline
\end{tabular}

${ }^{* * *} p<.001^{*} p<.0$

\section{Discussion}

In this study, difference in internet usage time according to the majors of university students was presumed to result in the difference in digital literacy ability as well. As for the major, it was found out that the students who major in human science is more likely to use computer for a longer time than those who major in computer science. This implies that students who major in human science rely on the internet for the acquisition of information even more than students who major gs in computer science who use computer itself more often. All though students who major in human science expressed difficulty in using computer technology, there was no significant difference in their ability to use and share information from that of who major in computer Therefore, the following conclusions can be made:

First, computer technology usage does not considerably affect digital literacy Instead, upon the analysis on the relationship between internet usage time and digital literacy ability, what showed a significant relationship with internet usage time among the digital literacy abilities was community information sharing ability. Second, 'time' is the invisible factor that reallocates social behavior through the use of computer.

Thus, since the total available time is limited, the distribution of time for various activities and the effects of new technology on time allocation will influence the choice of hardware and software as well.

Therefore, in designing educational software, increasing the time exposed to quality information and the creation of critical thinking should also be considered.

Third, an integrated and comprehensive approach among fields of knowledge that can bring a regeneration of knowledge is necessary.

If the education program that can develop a critical and cooperative thinking for those who major in computer science and the technology-based education for those who major in human science are combined, the re-generation of knowledge-and the usage of that knowledge as information will be made possible.

Furthermore, the following suggestions can be made for the measurement evaluation tool. First of all, the development of measuring tool to gauge the digital literacy level should be corrected and supplemented. The evaluation standard developed in the previous studies failed to put weight on the lower range. Different weights should be generated depending on the evaluation purpose and more especially, an index that can produce a prioritized area or indicator according to the subjects and their age should be developed as well

Second, the development of an item pool is necessary in order to measure digital literacy level. To measure this, the technology and knowledge for the evaluation of the digital literacy as per index must be more thoroughly classified and only through such detailed classification will the development of question items become easier.

Third, digital literacy capability evaluation should be designed in a way that it can help in the development of a cooperative and critical thinking process. The recent paradigm stresses on the community information sharing ability more than the computer use ability with ethical and social responsibilities as additional factors. Digital literacy ability evaluation should be designed to promote not only the utilization of information, but more ultimately the regeneration of knowledge through critical thinking. Though there-are various standards for evaluation, no feedback was made to them. A detailed feedback about the evaluation of community information sharing ability is necessary. Previous studies conducted research to gauge the current digital literacy level; however, they failed to provide a result. Therefore, not only a measurement of the students' knowledge capability should be developed, but also an education policy with regard to the teaching direction based on its results.

\section{Reference}

[1] Min Ha, Kim, Mi Ri, Ahn, Development of Digital Literacy Checklist, KEIM, 2003, pp3-10.

[2] Su Sang, Lee, A Survey Research on Information Literacy Level in Korean University Students , Journal of the Korean Library and Information Science Society, 2007, pp.4-10.

[3] Clariana, R., \& Wallace, P., Paper-based vs. Computer-based Assessment: Key Factors. 
Associated with the Test Mode Effect. British Journal of Educational Technology, 33(5), 2002, pp.593-602.

[4] Yang, Jung-Ho, Effects of High School ICT Activities on Students' Digital Literacy in Korea, Journal of Educational Technology Vol.28 No.2,2012, pp. 349352.

[5] Han, Jeong-seon et al., A Study on the Development of Digital Literacy Index for the Development and Support of Knowledge Information Competency, Korean Research Information Service, 2006, pp. Korean Research Information Service .

[6] Information literacy: An update on the American library association presidential committee on information literacy (finalreport). 2006, http://www.ala.org/ala/ acrl/acrlpubs/whitepapers/progressreport.htm

[7] MinJeoung, Kim, A Study on the Digital Literacy of Undergraduate and Graduate students, Sukmyung University M.A, 2011, pp.-17-28. 